\title{
Effect of Allium sativum on the Motility and Acetylcholinesterase of Haemonchus contortus
}

\author{
L. Veerakumari ${ }^{1}$, N. Chitra ${ }^{2}$ \\ Post graduate and Research Department of Zoology, Pachaiyappa's College, Chennai -600030, India
}

\begin{abstract}
Helminths are known to be a major constraint to ruminant's well-being and productive performance. Gastrointestinal helminths are widespread parasitic agents of livestock especially in small ruminants. Helminthiasis plays an important role in the small ruminant production leading to enormous economic losses in areas where extensive grazing is practiced. Haemonchosis is caused by the hematophagous parasite Haemonchus contortus. It is the most important parasites of all the gastrointestinal nematodes that constrain the survival and productivity of sheep and goats owned by rural farmers in the developing countries. In the present investigations anthelmintic effect of Allium sativum on the motility and acetylcholinesterase (AChE) of the nematode Haemonchus contortus were studied in vitro. The worms were exposed to various concentrations of hexane, chloroform, ethyl acetate, ethanol and aqueous extract of Allium sativum and the motility of the parasites were viewed. As ethanol extract was effective, further studies were conducted with various sublethal concentrations $0.005,0.01,0.05,0.1$ and $0.5 \mathrm{mg} / \mathrm{ml}$. Quantitative measurement of the motility of the parasites evidently showed the direct impact of the drugs on the parasite. Maximum inhibition in the motility (88.50\%) and AChE (90.25\%) was remarked in $0.5 \mathrm{mg} / \mathrm{ml}$ of AsEE after $8 \mathrm{~h}$ of exposure. AChE is concerned in muscularly harmonious combination and neurotransmission. The important role of this enzyme can stop cholinergic synaptic communication with immediate hydrolysis of the acetylcholine. Inhibition of AChE in the parasite results in paralysis of musculature and the parasite lose its biochemical holdfast and get expelled from the host. The present study clearly showed that AsEE had killed the parasites by affecting their neurotransmission.
\end{abstract}

Keywords: Allium sativum, Haemonchus contortus, Acetylcholinesterase.

\section{Introduction}

(GI) nematodes are a major threat to sheep productivity and endanger animal welfare in developing countries. Haemonchus Gastrointestinal contonus is an important blood sucking parasite of ovines and causes an insidious drain on production [1]. The disease caused by this parasite (Haemonchosis) is prevalent wherever, sheep and goats are raised, but it exerts the greatest economic losses in temperate and tropical regions [2]. Parasitism is one of the major factors limiting sheep and goat production because they cause heavy economic losses in meat and wool production [3]. Control is achieved by use of synthetic anthelmintics in combination with grazing management. Haemonchus contortus has been documented to be resistant to all three families of anthelmintics namely, benzimidazole, imidathiazole and ivermectin [4,5] and against drug with narrow spectrum of activity such as salicylanilides $[6,7,8]$. The frequent use of these anthelmintics over many years has inevitably led to the development of drug resistance to each class in parasitic nematodes. The emergence of resistance to anthelmintic drugs which is now a worldwide phenomenon [9] and the increased awareness of consumers about the food chain have stimulated investigation into alternative to commercially available anthelmintics such as medicinal plants. Many studies from various parts of the world have shown that certain plant species effectively reduce the degree of parasite infestation in ruminants (sheep) and are promising alternatives to conventional anthelmintics. Many of the plant species owe their anthelmintic effects to plant metabolites such as saponins, tannins and essential oils.

\section{Background of the Study}

Recent surveys in developing countries have identified many plants have the potential to be used as anthelmintics [10]. A wide range of plants and their products around the world are being explored for their possible anthelmintic effects against cestodes, trematodes [11] and nematodes [12]. Because of the economic impact of gastrointestinal parasitic nematodes in the livestock industry around the world, most of the research on plant extracts is being focused on identifying bioactive compounds from plants against nematodes. Allium sativum commonly called garlic belongs to the family Alliaceae. It has been used for centuries to fight infections [13]. It has traditional dietary and medicinal applications as an anti-infective agent [14]. A. sativum is an antioxidant [15], antibacterial, antiviral, antifungal and anti-parasitic $[16,17]$ antihypertensive [18], anthelmintic [19] and antidiabetic agent [20]. In veterinary practice, A. sativum is used for promotion of wound healing and treatment of infected wounds in calves [21]. The fresh bulb of A. sativum contains alliin, allicin and volatile oils. When the garlic clove is crushed, the odorless compound alliin is converted to allicin, by the enzyme allinase. Allicin gives garlic its characteristic pungent smell [22]. Volatile compounds are considered to be responsible for most of the pharmacological properties of garlic. Garlic contains at least 33 sulphur compounds, several enzymes, 17 amino acids and minerals such as selenium and germanium $[23,24,25,26]$. In the present investigation an attempt has been made to assess the efficacy of $A$. sativum against the H.contortus. The most important parameter used to gauge the anthelmintic property of a plant product is the motility of the parasites in vitro conditions. Motility is directly related to the neuromuscular system [27] which is well developed in nematodes [28]. Plant anthelmintics target the neuromuscular system of the worms 


\section{International Journal of Science and Research (IJSR) \\ ISSN (Online): 2319-7064 \\ Index Copernicus Value (2013): 6.14 | Impact Factor (2014): 5.611}

[29]. They block cholinergic nerve transmission and act through the stereo specific binding to a receptor resulting in muscle paralysis [30]. Therefore, the present investigation was undertaken to evaluate the anthelmintic efficiency of Allium sativum based on its effects on the motility and AChE of Haemonchus contortus in vitro.

\section{Materials and Methods}

\subsection{Collection and in vitro maintenance of $H$. contortus}

Adult female $H$. contortus were collected from the abomasum of sheep, slaughtered at Perambur slaughter house, Chennai. The worms were washed in physiological saline and maintained in Hedon-Fleig solution $(\mathrm{pH} \mathrm{7.0)}$ at $37^{\circ}$, which is the best medium for in vitro maintenance [31].

\subsection{Preparation of plant extracts}

The bulbs of Allium sativum was collected made into paste and soaked serially in hexane, chloroform, ethyl acetate, ethanol and water in an aspirator bottle and extracted by cold percolation method after $48 \mathrm{~h}$ [32]. The filtrate was collected by passing the mixture through Whatman filter paper No.1 and concentrated by using Rotary Evaporator (EQUITRON). The concentrated extracts were dried to remove the solvents using Lyodel freeze Dryer (DELVAC, Chennai).

\subsection{Gross visual observation on the motility of the worms}

Sixty milliliters of Hedon-Fleig solution containing various concentrations $(10,30$ and $50 \mathrm{mg} / \mathrm{ml})$ of the aqueous and solvent extracts were individually distributed in $100 \mathrm{ml}$ of conical flasks. Ten live and active parasites were incubated in various extracts. The activity of the worms was checked at various intervals $(5,15,30 \mathrm{~min}, 1,2,4,6,8,12$, and $24 \mathrm{~h})$ of exposure. Simultaneously, control was also maintained in Hedon-Fleig solution without the plant extracts. Based on the motility of the worms, the observations were categorized as active $(++++)$, moderately active $(+++)$, slightly active $(++)$, sluggish $(+)$ and dead $(-)$. The worms with no movement were regarded as dead. Based on the motility of the parasite for $8 \mathrm{~h}$ of exposure, five different sub-lethal concentrations were selected $(0.005,0.01,0.05,0.1$ and 0.5 $\mathrm{mg} / \mathrm{ml}$ ) for further studies.

3.4 Quantitative measure of motility response of drugtreated worms using Electronic Micromoility Meter (EMM)

The parasites were incubated for 2,4 and $8 \mathrm{~h}$ in the various sub-lethal concentrations of the plant extracts for further in vitro studies. The motility response of drug-treated parasites was recorded with the aid of Electronic Micromotility Meter (EMM) [33]. The motility of the worms was measured at $360 \mathrm{~nm}$ with 10 seconds time interval for $3 \mathrm{~min}$. The percentage of inhibition in the motility of the parasites was calculated following the formula,

$$
\% \text { inhibition of motility }=\frac{\mathrm{C}-\mathrm{T}}{\mathrm{C}} \times 100
$$

Where, C - Deviation of voltage signal in the control worm and $\mathrm{T}$ - Deviation of voltage signal in the worm treated with plant extracts.

\subsection{Estimation of Acetylcholinesterase}

The acetylcholinesterase (AChE) (EC 3.1.1.7) activity was tested using photometric method as described by Ellman et al [34]. Acetylthiocholine is a substrate hydrolyzed by AChE in the sample and forms thiocholine which will react rapidly and irreversibly with 5-thio-bis-nitrobenzoic acid (DTNB) producing a yellow anion of 5-thio-2-nitrobenzoic acid. The increase in color intensity is measured spectrophotometrically at $412 \mathrm{~nm}$.

\section{AChE}

Acetylthiocholine $\longrightarrow$ Thiocholine + acetate

Thiocholine + di thionitrobenzoate $\longrightarrow$ Yellow color

The sample for the enzyme test was prepared by homogenizing $100 \mathrm{mg}$ of control and treated parasites in 1 $\mathrm{ml}$ of $0.1 \mathrm{M}$ phosphate buffer ( $\mathrm{pH} 8.0)$. The homogenate was centrifuged at $1000 \mathrm{rpm}$ for $5 \mathrm{~min}$. To $0.1 \mathrm{ml}$ of the supernatant, $1.3 \mathrm{ml}$ of $0.1 \mathrm{M}$ phosphate buffer $(\mathrm{pH} 8.0), 0.05$ $\mathrm{ml}$ of $0.01 \mathrm{M}$ DTNB and $0.02 \mathrm{ml}$ of $0.075 \mathrm{M}$ acetythiolcholine iodide were added and mixed well. The reaction mixture was transferred to a cuvette and the absorbance was measured at $412 \mathrm{~nm}$ in a UV-Visible double beam biospectrophotometer. The absorbance was noted for $3 \mathrm{~min}$ at an interval of $15 \mathrm{sec}$ and the change in absorbance per minute $(\triangle \mathrm{A})$ was calculated. $\mathrm{AChE}$ activity was calculated using the formula.

$$
\mathrm{R}=5.74 \times 10^{-4} \mathrm{X} \frac{\Delta \mathrm{A}}{\text { Protein content of the sample }}
$$

$\triangle \mathrm{A}$ - Increase in absorbance per minute.

The protein content of the sample was estimated following the procedure of Lowry et al [35]. The enzyme activity was expressed as number of moles of acetylthiocholine iodide hydrolyzed/ $\mathrm{min} / \mathrm{mg}$ protein.

\subsection{Statistical Analyses}

The experimental results were expressed as mean \pm standard deviation. Each value is expressed as mean of triplicate experiments. Statistical analyses were performed by ANOVA using SPSS version 20 for different concentration of ethanol extract of $A$. sativum.

\section{Results and Discussion}

The present investigation enlightened the anthelmintic efficiency of ethanol extract of A. sativum (AsEE) on the viability and motility against $H$. contortus (Table 1 ). The ethanol extract of $A$. sativum (AsEE) was found to be more effective against $H$. contortus. Therefore five sub-lethal concentrations $0.005,0.05,0.01,0.1$ and $0.5 \mathrm{mg} / \mathrm{ml}$ of $A s \mathrm{EE}$ was selected for further in vitro studies and the motility response of parasites at sub-lethal concentrations were recorded in the table 2. The percentage of inhibition on motility by $A s \mathrm{EE}$ are $52.50 \%, 78 \%$ and $88.50 \%$, after 2,4 


\section{International Journal of Science and Research (IJSR) \\ ISSN (Online): 2319-7064 \\ Index Copernicus Value (2013): 6.14 | Impact Factor (2014): 5.611}

and $8 \mathrm{~h}$ exposure at higher sub-lethal concentration 0.5 $\mathrm{mg} / \mathrm{ml}$ (Table 3). Dose and time dependent inhibition in $\mathrm{AChE}$ activity was observed in drug treated parasites. Inhibition in AChE activity by $A s E E$ at $0.5 \mathrm{mg} / \mathrm{ml}$ was found to be $50 \%, 82.43 \%$ and $90.25 \%$ after 2,4 and $8 \mathrm{~h}$ respectively (Table 4). The present study revealed the destructive effect of AsEE on the motility and AChE of $H$. contortus. All effective anthelmintics directly or indirectly affect the motility of the parasite. EMM is an instrument fabricated with spectacular advancements to record the motility of the parasites. Electronic measurement of the motility of the parasite clearly shows the direct impact of the drug on the parasite.

$\mathrm{AChE}$ is an enzyme broadly spread in many species, including parasites. The presence of esterase has been showed in many helminth parasites [36, 37, 38]. Many roles have been proposed for AChE, including a biological hold fast', inhibition of mucus secretion and modulation of host immune response. Although few other roles have also been applied to AChE, the primary function of this enzyme is to limit the cholinergic synaptic transmission, by rapid hydrolysis of the neurotransmitter acetylcholine (Ach) [39, 40]. AChE is thus proved to be a functional protein, involved in multifaceted activities, which can serve as a suitable candidate for diagnostic purposes. The principal role of $\mathrm{AChE}$ is termination of transmission at cholinergic synapses by rapid hydrolysis of the neurotransmitter, acetylcholine [41].

The inhibition of AChE results in the accumulation of endogenous acetylcholine, thereby disrupt the neuromuscular transmission. According to Kaur et al [42] and Opperman et al [43], drug-induced interruption of the neuromuscular transmission leads to paralysis of musculature. Consequent to inactivation of neuromuscular coordination, active swallowing and movement of food through the digestive tract is arrested. The parasites thus entered starvation and energy deprivation. The energy-deprived worms unable to sustain themselves in situ are expelled by the host. AChE is thus proved to be a functional antigen, involved in multifaceted activities, and can therefore serve as a suitable candidate for both diagnostic purposes, vaccine development, and drug design. This study will help us to develop anthelmintic drug of natural origin with attitude to combat various anthelmintic infection. A. sativum is highly effective against helminths infection of small ruminants and it is necessary to identify and isolate the possible active phytoconstituents responsible for the anthelmintic activity. It is targeted platform for pharmacological studies and development of novel anthelmintic drug products to fill a gap in the anthelmintic drug industry, which is facing the crisis of anthelmintic resistance to conventional anthelmintic drugs.

\section{Conclusion}

The present studies showed that ethanol extract of A. sativum have anthhelmintic activities against Haemonchus contortus. From these observations, it can be assumed that the bulbs of A. sativum are the good sources of traditional medicines for helmintic infections and further studies would be attempted for isolation, purification and identification of potential compounds from plant extract.

\section{Acknowledgements}

We gratefully acknowledge University Grant commission (UGC), for funding this project.

Table 1: Gross visual observation on the motility of $H$. contortus treated with various extracts of $A$. sativum

\begin{tabular}{|c|c|c|c|c|c|c|c|c|c|c|c|}
\hline Extracts & Conc. $\mathrm{mg} / \mathrm{ml}$ & $5 \mathrm{~min}$ & $15 \mathrm{~min}$ & $30 \mathrm{~min}$ & $1 \mathrm{~h}$ & $2 \mathrm{~h}$ & $4 \mathrm{~h}$ & $6 \mathrm{~h}$ & $8 \mathrm{~h}$ & $12 \mathrm{~h}$ & $24 \mathrm{~h}$ \\
\hline \multicolumn{2}{|c|}{ Control } & ++++ & ++++ & ++++ & ++++ & ++++ & ++++ & ++++ & ++++ & ++++ & ++++ \\
\hline \multirow{3}{*}{$A s \mathrm{HE}$} & 10 & ++++ & ++++ & ++++ & +++ & +++ & ++ & ++ & ++ & - & - \\
\hline & 30 & ++++ & +++ & +++ & +++ & +++ & ++ & + & + & + & - \\
\hline & 50 & +++ & +++ & +++ & ++ & ++ & + & + & - & - & - \\
\hline \multirow{3}{*}{$A s \mathrm{CE}$} & 10 & ++++ & ++++ & ++++ & ++++ & +++ & +++ & ++ & + & - & - \\
\hline & 30 & +++ & +++ & +++ & +++ & +++ & ++ & + & + & - & - \\
\hline & 50 & ++ & ++ & + & + & - & - & - & - & - & - \\
\hline \multirow{3}{*}{ As $\mathrm{EaE}$} & 10 & ++++ & ++++ & ++++ & ++++ & ++++ & +++ & ++ & + & + & - \\
\hline & 30 & +++ & +++ & +++ & +++ & ++ & + & + & + & - & - \\
\hline & 50 & +++ & ++ & ++ & ++ & + & - & - & - & - & - \\
\hline \multirow{3}{*}{$A s \mathrm{EE}$} & 10 & +++ & ++ & + & + & - & - & - & - & - & - \\
\hline & 30 & ++ & + & + & - & - & - & - & - & - & - \\
\hline & 50 & ++ & + & + & - & - & - & - & - & - & - \\
\hline \multirow{2}{*}{ AsAE } & 10 & ++++ & +++ & +++ & +++ & +++ & +++ & +++ & +++ & +++ & +++ \\
\hline & 50 & +++ & +++ & +++ & ++ & ++ & + & + & + & - & - \\
\hline
\end{tabular}

++++: Very active; +++: Moderately active; ++: Slightly active; + : Sluggish; - : Dead

As HE - A. sativum hexane extract; AsCE - A. sativum chloroform extract; AsEaE - A. sativum ethyl acetate extract; AsEE - A. sativum ethanol extract; As AE - A. sativum aqueous extract. 


\section{International Journal of Science and Research (IJSR) \\ ISSN (Online): 2319-7064}

Index Copernicus Value (2013): 6.14 | Impact Factor (2014): 5.611

Table 2: Gross visual observation on the motility of $H$. contortus treated with sub-lethal concentrations of ethanol extract of A.sativum

\begin{tabular}{|c|c|c|c|c|c|c|c|c|c|c|c|}
\hline Extracts & $\begin{array}{l}\text { Conc. } \\
\mathrm{mg} / \mathrm{ml}\end{array}$ & $5 \mathrm{~min}$ & $15 \mathrm{~min}$ & $30 \mathrm{~min}$ & $1 \mathrm{~h}$ & $2 \mathrm{~h}$ & $4 \mathrm{~h}$ & $6 \mathrm{~h}$ & $8 \mathrm{~h}$ & $12 \mathrm{~h}$ & $24 \mathrm{~h}$ \\
\hline \multicolumn{2}{|c|}{ Control } & ++++ & ++++ & ++++ & ++++ & ++++ & ++++ & ++++ & ++++ & ++++ & ++++ \\
\hline \multirow{5}{*}{$A S E E$} & 0.005 & ++++ & ++++ & ++++ & +++ & ++++ & +++ & +++ & +++ & +++ & ++ \\
\hline & 0.01 & ++++ & ++++ & ++++ & ++++ & ++++ & +++ & +++ & ++ & ++ & + \\
\hline & 0.05 & ++++ & ++++ & ++++ & ++++ & +++ & +++ & ++ & ++ & ++ & + \\
\hline & 0.1 & ++++ & ++++ & ++++ & +++ & +++ & ++ & ++ & + & + & - \\
\hline & 0.5 & ++++ & ++++ & ++++ & +++ & ++ & ++ & ++ & + & + & - \\
\hline
\end{tabular}

++++ : Very active; +++: Moderately active; ++: Slightly active; +: Sluggish; -: Dead

Table 3: Effect of ethanol extract of $A$. sativum on the motility of $H$. contortus

\begin{tabular}{|c|c|c|c|}
\hline \multirow{2}{*}{$\begin{array}{c}\text { Conc. } \\
\mathrm{mg} / \mathrm{ml}^{*}\end{array}$} & \multicolumn{3}{|c|}{$\begin{array}{c}\text { inhibition (mean } \pm \mathrm{SD} \text { of } \mathrm{n}=5 \text { ) at various } \\
\text { periods of incubation** }\end{array}$} \\
\cline { 2 - 4 } & $2 \mathrm{~h}$ & $4 \mathrm{~h}$ & $8 \mathrm{~h}$ \\
\hline \multicolumn{4}{|c|}{ AsEE } \\
\hline 0.005 & $24.50 \pm 0.47$ & $59.80 \pm 0.31$ & $70.30 \pm 0.57$ \\
\hline 0.01 & $31.00 \pm 0.31$ & $65.20 \pm 0.47$ & $74.90 \pm 0.39$ \\
\hline 0.05 & $35.20 \pm 0.40$ & $71.00 \pm 0.40$ & $79.40 \pm 0.39$ \\
\hline 0.1 & $47.70 \pm 0.57$ & $74.00 \pm 0.47$ & $83.20 \pm 0.30$ \\
\hline 0.5 & $52.20 \pm 09.41$ & $78.00 \pm 0.38$ & $88.50 \pm 0.50$ \\
\hline
\end{tabular}

* Inhibitory effects of the extracts among the different concentrations of the respective plants are duration of incubation $(\mathrm{P}<0.05)$ using Duncan principle comparisons.

** Inhibitory effects of the extracts among the different hours of incubation is significantly different for each concentration of the respective plants $(\mathrm{P}<0.01)$ Duncan principle comparisons.

Table 4: Effect of ethanol extract of A. sativum on the AChE of $H$. contortus

\begin{tabular}{|c|c|c|c|}
\hline \multirow{2}{*}{$\begin{array}{c}\text { Conc. } \\
\mathrm{mg} / \mathrm{ml} l^{*}\end{array}$} & \multicolumn{3}{|c|}{$\begin{array}{c}\text { inhibition (mean } \pm \mathrm{SD} \text { of } \mathrm{n}=5 \text { ) at various } \\
\text { periods of incubation** }\end{array}$} \\
\cline { 2 - 4 } & $2 \mathrm{~h}$ & $4 \mathrm{~h}$ & $8 \mathrm{~h}$ \\
\hline \multicolumn{4}{|c|}{$A s \mathrm{EE}$} \\
\hline 0.005 & $25.00 \pm 0.29$ & $60.07 \pm 0.41$ & $75.03 \pm 0.13$ \\
\hline 0.01 & $33.33 \pm 0.37$ & $67.37 \pm 0.67$ & $80.31 \pm 0.21$ \\
\hline 0.05 & $37.50 \pm 0.16$ & $70.48 \pm 0.68$ & $83.75 \pm 0.14$ \\
\hline 0.1 & $41.66 \pm 0.2$ & $73.64 \pm 0.20$ & $88.35 \pm 0.14$ \\
\hline 0.5 & $50.00 \pm 0.1$ & $82.43 \pm 0.12$ & $90.25 \pm 0.17$ \\
\hline
\end{tabular}

* Inhibitory effects of the extracts among the different concentrations of the respective plants are duration of incubation $(\mathrm{P}<0.05)$ using Duncan principle comparisons. ** Inhibitory effects of the extracts among the different hours of incubation is significantly different for each concentration of the respective plants $(\mathrm{P}<0.01)$ Duncan principle comparisons

\section{References}

[1] M. Z. Hussain and M. Akram. Hostparasite relationship. Studies on the productivity of sheep as affected by haemonchosi. Pakistan Journal of Sciences, 5: 247-251, 1967.

[2] D. C. Blood, J. A. Henderson and M. Radostits. Veterinary Medicine. 5th Ed., Bailliere Tindall, London, UK, 1979.

[3] M. C. Gordon and J. N David. Natural product drug discovery in the next millennium. Journal of Biological and Pharmaceutical Research, 39: 8-17. 2001.

[4] R. Rrichard. Anthelmintic resistance in nematodes: extent, recent understanding and future direction for control and research. Int. J. Pharmacol., 29: 515-523, 1990.

[5] D. Singh, C. P. Swarnkar, and F. A. Khan. Anthelmintic resistance in gastrointestinal nematodes of livestock in India. J. Vet. Parasitol., 16(2): 115-130, 2002.

[6] P. F. Rolfe, J. C. Boray, C. Fitzgibbon, G. Persons, P. Kemley, and N. Sangste. Closental resistance in Haemonchs contortus from sheep. Aus. Vet. J., 67: 29341,1990 .

[7] D. Singh, C. P. Swarnkar, P. S. K. Bhagwan and Dimri. rafoxanide in sheep. J. Vet. Parasitolo., 10: 53-567, 1996.

[8] C. P. Swarnkar, D. Singh, F. A. Khan, and P. S. K. Bhagwan. Multiple anthelmintic resiatance in Haemonchs contortus of sheep. Indian. J. Anim. Sci., 69: 547-549, 1999.

[9] F. Jackson, and R. L. Coop. Development of anthelmintic resistance in sheep nematodes. Parasitolo., 20: 95-107, 2000.

[10] K. Sawleha Qadir, and D. Pooja. Veterinary world, Vol. 3 (11): 515- 518, 2010.

[11]F. Abdel-Ghaffar, M. Semmler, A. Khaled, S. AlRasheid, B. Strassen, K. Fischer, G. Aksu, S. Klimpel, H. Mehlhorn. The effects of different plant extracts on intestinal cestodes and on trematodes. Parasitology Research 108:979-984, 2011.

[12]R. Kalip Datsu, A. Slyranda Baltini, A. Wycliff, F. I. Abdulrahaman. Preliminary phytochemical screening and in vitro anthelmintic effects of aqueous extracts of Salvadora persica and Terminalia avicennoides against strongyline nematodes of small ruminants in Nigeria. Journal of Animal and Veterinary Advances, 10 (4):437442, 2011

[13]R. A. Onyeagba, O. C. Ugbogu, C. U. Okeke, and O. Iroakasi. Studies on the antimicrobial effects of garlic (Allium sativum Linn), ginger (Zingiber officinale Roscoe) and lime (Citrus aurantifolia Linn). Afr. J. Biotechnol., 3(10): 552-554, 2006.

[14]Z. M., O. Ross, E. A. Gara, D. J. Hill, H. V. Sleightholme and D. J. Maslin. Antimicrobial Properties of Garlic Oil against Human Enteric Bacteria: Evaluation of Methodologies and Comparisons with Garlic oil, Sulfides and Garlic Powder. Appl. Environ. Microbiol. 67: 475-480, 2001.

[15] J. Kleijnen, P. Knipschild, and G. Ter Riet. Garlic, onion and cardiovascular risk factors: A review of the evidence from human experiments with emphasis on commercially available preparations. British J. Clin. Pharmacol., 28: 535-544, 1989. 


\section{International Journal of Science and Research (IJSR) \\ ISSN (Online): 2319-7064}

Index Copernicus Value (2013): 6.14 | Impact Factor (2014): 5.611

[16]Hughes and Lawson. Antimicrobial effects of Allium sativum L. (garlic), Allium ampeloprasum L. (Elephant Garlic), and Allium cepa L. (Onion), garlic compounds and commercial garlic supplements. Phytotherapy Research, 5(4):154-158, 1991

[17] S. Ankri and D. Mirelman. Antimicrobial properties of allicin from garlic. Microbes and Infection, 2:125-129, 1999.

[18]C. A. Silagy, and A. W. Neil. A meta-analysis of the effect of garlic on blood pressure. J.Hyperten., 12:463468, 994.

[19]Z. Iqbal,Q. K. Nadeem, M. N. Khan, M. S. Akhtar, and F. N. Waraich. In vitro anthelmintic activity of Allium sativum, Zingiber officinale, Curcurbita mexicana and Ficus religiosa. Int. J. Agri. Biol., 3(4): 454-457, 2001.

[20] L. C. Thompson, J. E. Ladner, S. G. Codreanu, J. Harp, G. L. Gilliland and R. N. Armstrong. 2Hydroxychromene-2-carboxylic acid isomerase: a kappa class glutathione transferase from Pseudomonas putida. Biochemistry., 46: 6710-6722, 2007.

[21] P. Josling. The antiviral effects of A. sativum. In: Mostly A. sativum Magazine. The A. sativum Center, 2000.

[22] E. Williamson. Potter's Herbal Cyclopaedia. London: C.W. Daniel, 2003.

[23] C. A. Newall, L. A. Anderson, and J. D. Phillipson. Herbal medicines: a guide for health-care professionals. London: Pharmaceutical Press, IX: 296, 1996.

[24] M. Castleman. The New Healing Herbs. Emmaus, PA: Rodale Press, 2001.

[25] J. Barnes, L. Anderson and D. Phillipson. Herbal Medicines 2nd ed. London: Pharmaceutical Press, 2002.

[26]L. Skidmore-Roth. Handbook of Herbs and Natural Supplements $2^{\text {nd }}$ ed. St. Louis: Mosby, 2003.

[27]D. Kumar, S. Chandra and H. C. Tripathi. In vitro motility recording of Fasciola gigantica. J. Vet. Parasitol., 9(1): 31-36, 1995.

[28] T. G. Geary, R. D. Klein, L. Vanover, J. W. Bowman and D. P. Thompsom. The nervous systems of helminths as targets for drugs. J. Parasitol., 78: 215-230, 1992.

[29]R. Arnon, S. Israel and Rrebeca tarrab-hazdai. Acetylcholinesterase of Schistosoma mansoniFunctional correlates Protein Science. 1999, 8:25532561. Cambridge University Press. Printed in the USA, 1999.

[30]G. Hrckova and V. Samuel. V. Pharmacological Potential of Selected Natural Compounds in the Control of Parasitic Diseases. SpringerBriefs in pharmaceutical science \& drug development, ISSN 1864-8118, 2013.

[31] Veerakumari, L., 1996. In vitro studies on the effect of some anthelmintics on Cotylophoron cotylophorum (Fischoeder, 1901) (Digenea: Paramphistomidae). A structural and biochemical analysis, Ph.D. thesis, University of Madras. Chennai.

[32] J. B. Harborne. Phytochemical Methods. London: Chapman and Hall limited; 1973.

[33]L. Veerakumari. Micromotility meter: an instrument to evaluate the efficacy of anthelmintic drugs. In: Proceedings of Fourteenth National Congress of Indian Association for the Advancement of Veterinary parasitology. Maske, D. E., Kolte, S. W., Banubakade, S. B. and Kurkure, N. V. (Eds.) Nagpur, India, pp. 152, 2003.
[34] G. L. Ellman, K. D. Courtney, V. Andrews and R. M. Featherstone. A new and rapid calorimetric determination of acetylcholinesteraseactivity. Biochem. pharamcol., 1: 88-95, 1961.

[35] O. H. Lowry, N. J. Rosebrough, A. L. Farr and R. J. Randall. Protein measurement with the Folin phenol reagent. J. Biol. Chem., 193: 265-275, 1951.

[36] A. N. Gupta and P. P. Sood. Non-specific esterase and its involvement in the dynamism of outer body covering of trematodes, cestodes and nematodes. Acta. Histochem., 50: 124-130, 1974.

[37]M. P. Balasubramanian, K. Nellaiappan and K. Ramalingam. Characterization of esterase isoenzymes of Raillietina tetragona (Molin, 1858) (Cestoda. Vet. Parasitol., 10: 313-316, 1982.

[38]D. W. Halton. Morphology and ultrastructure of parasitic helminths. In: Parasites - Their world and ours. Mettrick, and Dessers, S. (Eds.). Elsevier, Biochemical Press, Amsterdam, pp. 60-69, 1982.

[39]D. Prichard. Why do some parasitic nematodes secrete acetylcholinesterase (AChE) Int. J. Parasitol., 23: 549. $550,1993$.

[40]D. L. Lee. Why do some nematode parasites of the alimentary tract secrete acetylcholinesterase. Int. J. Parasitology., 26: 499-508, 1996.

[41]M. A. Taylor. A larval development test for the detection of anthelmintic resistance in nematodes of sheep. Research in Veterinary Science, 49:198-202, 1990.

[42] R. Kaur and M. L. Sood. In vitro effect of antheelmintics on Mailc enzyme and cholinesterase of Haemonchus contortus (Nematoda: Trichostrongylidae). Ind. J. Parasitol., 6:267-268, 1982b.

[43]C. Opperman and S. Chang. Nematode acetylcholinesterase: Molecular forms and their potential role in nematode behaviour. Parasitology Today, 8:406-410, 1992.

\section{Author Profile}

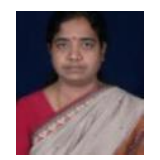

Dr. (Mrs)L. Veerakumari, Associate Professor \& Head, PG \& Research Department of Zoology, Pachaiyappa's College, Chennai, Tamil Nadu, India has thirty five years of teaching and research experience. She has received her $\mathrm{PhD}$ degree from University of Madras, India in 1997. She is a life member of Indian Association for the Advancement of Veterinary Parasitology, Indian society of Parasitology, Indian Association of Biomedical Scientists, Indian Association of physiologists and pharmacologists, Indian Society of education and environment, Indian Association of Science and technology and Indian Science Congress Association. She has authored two books and has published many research papers. She has completed six research projects funded by UGC, DST and TNSCST. She is a Gold medalist and received many best paper awards, MABMS and FABMS Title, Best researcher award, Bharat Jothi award, Ismail oration award and Inducted into the American order of Scientific and technical merit

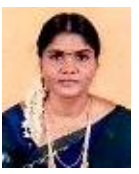

Mrs. Chitra. N. is Ph. D. Reasearch Scholar, PG and Research Department of Zoology, Pachaiyappa's College, Chennai - 600 030. Currently she is doing $\mathrm{Ph} . \mathrm{D}$. (Full-time) in the field of veterinary Pasitology under the able guidance of Dr.L.Veerakumari 